\title{
Accidents in agriculture in the Kraśnik district in 2011 compared to the Agricultural Social Insurance Fund (KRUS) data
}

\begin{abstract}
Introduction. Injuries are one of the major problems of modern medicine, especially for the employees of the agricultural sector, due to the nature and conditions of work. Given the dominance of this sector of employment in Kraśnik district, this problem requires a careful analysis to determine the strategy for the prevention of injuries in agriculture and the removal of their consequences.

Aim. The purpose of this paper is to characterize injuries of farmers in the Kraśnik district, their correlation with the seasonal intensity of work and to determine age groups and gender of those most vulnerable .

Material and methods. The representative group consisted of 102 patients residing in the Kraśnik district, treated for injuries incurred during the work related to agriculture and selected from 912 patients treated in the Department of Trauma Surgery Unit of Orthopedic Subdivision of Health Care Unit (SPZOZ) in Kraśnik in 2011.

Results. The analyzed material shows that the most common in the Kraśnik district are injuries of the upper limbs of the male population of farmers aged 40-49 years. These injuries occur more often in winter than in summer, usually in the afternoon. Apart from the accident rate, which for the Lublin province is higher than for other areas of Poland, this data does not significantly deviate from the Agricultural Social Insurance Fund (KRUS) data. However, this research reveals a population of children and young people aged up to 18 years representing $9.8 \%$ of all hospitalized due to injuries on the farm, which, due to the nature, are not taken into account in Agricultural Social Insurance Fund data, although it is an important social issue.

Conclusions. Injuries in agriculture in Kraśnik district usually occur amongst middle-aged men (40-49 years). Injuries that occur while working in agriculture are usually injuries of the upper and lower limbs and are characterized by seasonal occurrence and usually occur in the winter and the summer months.
\end{abstract}

Keywords: Kraśnik district, injuries, agriculture, Agricultural Social Insurance Fund (KRUS).

DOI: $10.12923 / j .0044-2011 / 123-4 / a .02$

\section{INTRODUCTION}

Injuries and their consequences are one of the leading problems of modern medicine. The consequences of injuries are the second leading cause of disability and the third leading cause of death after cardiovascular disease and cancer [1-4]. In 2011, 25,772 accidents were reported to Agricultural Social Insurance Fund (KRUS), the majority of accidents occurred on farms ranging in size from 1 to 5 hectares $(28.1 \%)$ and from 5 to 10 hectares $(25.9 \%)$, with a mixed production profile $(64.2 \%)$.

In terms of employment, the agricultural sector is the dominant sector of the economy of the Kraśnik district. In total, there are about 15.7 thousand farms, of which nearly $70 \%$ are farms ranging in size from 1 to 10 ha. The average farm size in the district is 4.7 ha, well below the average recorded in the province (6.9 ha). Half of the farms are run by people who have no agricultural education. People with higher agricultural education run only one percent of the farms. The farms are relatively well equipped with agricultural machinery. The number of tractors and combine harvesters per 100 households in the district is comparable with the province and the country (Table 1) [5].

Accidents in private farms are associated with the specifics of work in agricultural family farms, including the need to perform a variety of tasks that require different skills. A farmer performs typical farming works - breeds animals,

TABLE 1. The equipment of farms with agricultural machinery.

\begin{tabular}{lcccc}
\hline \hline $\begin{array}{c}\text { Number of } \\
\text { agricultural } \\
\text { equipment } \\
\text { per } 100 \text { farms }\end{array}$ & Tractors & Lorries & $\begin{array}{c}\text { Combine } \\
\text { grain } \\
\text { harvesters }\end{array}$ & $\begin{array}{c}\text { Combine } \\
\text { potato } \\
\text { harvesters }\end{array}$ \\
\hline $\begin{array}{l}\text { Kraśnik } \\
\text { district }\end{array}$ & 55 & 3,5 & 6.4 & 2.5 \\
\hline Poland & 46 & 5 & 4.2 & 3 \\
\hline
\end{tabular}

\footnotetext{
${ }^{1}$ Independent Public Health Care in Kraśnik, Poland

${ }^{2}$ General Surgery Department of the Independent Public Health Care Unit in Kraśnik, Poland

${ }^{3}$ II Faculty of Medicine with the English Division, Department of Public Health, Medical University of Lublin, Poland
} 
maintains machinery and equipment for agricultural production, as well as he or she does minor carpentry, electrical and construction works. In the harvest period, there is an intensification of work and the need for many hours of hard, monotonous work. In the farmer's work environment there are numerous threats - direct contact with animals and pathogenic biological agents, exposure to noise, dust, vibration, exposure to difficult and often changing weather conditions (heat, cold and rain) [6].

\section{AIM}

The purpose of this paper was to obtain information about the characteristics of injuries of the farmers in the Kraśnik district, their correlation with the seasonal intensity of work and the determination of age groups and gender of those most vulnerable to injuries.

\section{MATERIAL AND METHODS}

The representative group was selected from 912 patients treated in the Department of Trauma Surgery Unit at the Orthopedic Subdivision of Health Care Unit (SPZOZ) in Kraśnik in 2011. After analyzing the medical records, there were selected 102 patients residing in Kraśnik district, treated for injuries incurred during the work related to agriculture.

The data obtained allowed to assess the relationship between the severity of the accident and the time of year, the reasons for the resulting injuries and their relation to gender and age. This data was then compared to Agricultural Social Insurance Fund (KRUS) for individual farming in Poland in 2011.

\section{RESULTS}

In 2011, the accident rate (number of accidents that resulted in the one-time payment by Agricultural Social Insurance Fund (KRUS) per 1000 insured) in private farms in Poland was 10.9 and in the Lublin province it was 12.4. Most accidents reported were among men (69.3\% of victims). Most affected were the individuals in the following age groups: $50-59$ years $(23.5 \%$ of all victims were male and $11.1 \%$ female $), 40-49$ years $(21.8 \%$ men and $10.5 \%$ women $)$ and $30-39$ years (14.8\% men and $6.7 \%$ of women) [6].

Amongst the treated in the Department of Trauma Surgery at Orthopedic Subdivision of Health Care Unit (SPZOZ) in Kraśnik, the majority were men (71.6\%), with the highest accident rate observed in the age group $40-49$ years $(24.5 \%$ of all victims were men and $7.8 \%$ women), and $50-59$ years (18.6\% men and 10.8\% women). Most injuries were suffered by workers performing physical work on the farm, but a significant proportion was that of young people before the age of eighteen years (of which $8.8 \%$ were boys and $1 \%$ girls). However, no injuries were registered of people aged 65 years and older (Table 2).

During accidents in agriculture, according to Agricultural Social Insurance Fund (KRUS) national data, the most vulnerable areas of the body are upper limb $49.57 \%$ and lower limb $37.69 \%$. These values weresimilarin Kraśnik districtwheremost frequentwereinjuries of the upper limb $42.16 \%$ and lower limb $27.45 \%$. Further, down the place there were respectively the head and neckinjuries $(18.63 \%)$ and then collectively chest, spine, abdomen and pelvis injuries $-11.76 \%$ (Table 3).

Seasons also have a significant impact on the number of injuries. As shown in the analysis of the collected material, the accidents occurred most frequently in winter $(33.3 \%)$,

TABLE 2. The age and sex of persons injured in accidents in 2011.

\begin{tabular}{|c|c|c|c|c|c|c|c|c|c|c|}
\hline \multirow[t]{2}{*}{ Area } & \multirow[t]{2}{*}{ Gender } & & \multicolumn{8}{|c|}{ The number of accidents in the age groups } \\
\hline & & Total & $<18$ & $18-19$ & $20-29$ & $30-39$ & $40-49$ & $50-59$ & $60-64$ & $\geq 65$ \\
\hline \multirow{4}{*}{$\begin{array}{l}\text { Poland } \\
\text { Agricultural } \\
\text { Social Insurance } \\
\text { Fund (KRUS) data }\end{array}$} & Men & 11478 & 0 & 31 & 1215 & 2449 & 3609 & 3887 & 252 & 39 \\
\hline & $\%$ & 69.30 & 0 & 0.2 & 7.3 & 14.8 & 21.8 & 23.5 & 1.5 & 0.2 \\
\hline & Women & 5096 & 0 & 0 & 306 & 1117 & 1743 & 1840 & 51 & 39 \\
\hline & $\%$ & 30.70 & 0 & 0 & 1.8 & 6.7 & 10.5 & 11.1 & 0.3 & 0.2 \\
\hline \multirow{4}{*}{ Kraśnik district } & Men & 73 & 9 & 5 & 5 & 9 & 25 & 19 & 1 & 0 \\
\hline & $\%$ & 71.6 & 8.8 & 4.9 & 4.9 & 8.8 & 24.5 & 18.6 & 1 & 0 \\
\hline & Women & 29 & 1 & 0 & 3 & 4 & 8 & 11 & 2 & 0 \\
\hline & $\%$ & 28.4 & 1 & 0 & 2.9 & 3.9 & 7.8 & 10.8 & 1.9 & 0 \\
\hline
\end{tabular}

TABLE 3. Characteristics of the anatomical location of injuries.

\begin{tabular}{lcc}
\hline \hline Structure of injuries & Kraśnik district & $\begin{array}{c}\text { Poland, Agricultural } \\
\text { Social Insurance Fund } \\
\text { (KRUS) data }\end{array}$ \\
\cline { 2 - 3 } & \multicolumn{2}{c}{ The value in \% } \\
\hline Upper limb & 42.16 & 49.57 \\
\hline Lower limb & 27.45 & 37.69 \\
\hline Head and neck & 18.63 & 6.46 \\
\hline $\begin{array}{l}\text { Chest, spine, } \\
\text { abdomen and pelvis }\end{array}$ & 11.76 & 6.27 \\
\hline
\end{tabular}

TABLE 4. The occurrence of injuries depending on the season.

\begin{tabular}{|c|c|}
\hline Season & Occurrence of injuries in $\%$ \\
\hline Spring & $22.50 \%$ \\
\hline Summer & $30.40 \%$ \\
\hline Autumn & $13.70 \%$ \\
\hline Winter & $33.30 \%$ \\
\hline
\end{tabular}

TABLE 5. Characteristics of admissions, depending on the time of day.

\begin{tabular}{lc}
\hline \hline Patient admission hours & $\%$ \\
\hline From 0.00 to 12.00 & 37.3 \\
\hline From 12.00 to 0.00 & 62.7 \\
\hline
\end{tabular}


in summer $(30.40 \%)$ and in spring $-22.50 \%$ (Table 4 ); the number of injuries was also influenced by the time of day, as more injuries occurred in the afternoon $62.7 \%$ than before noon $37.3 \%$ (Table 5).

\section{DISCUSSION}

The data presented here indicate that the largest group of accident victims during work on the farm are men aged 40-49 years $(24.5 \%)$ and $50-59$ years (18.6\%). Therefore, Kraśnik district does not differ significantly from the Agricultural Social Insurance Fund (KRUS) national data where traumatism is the highest among men aged 50-59 years (23.5\%) and $40-49$ years $(21.8 \%)$. This slight shift may only represent a lower average age of farmers in the Kraśnik district, which is quite satisfactory and desirable. Disturbing is the fact that 9.8\% injuries are noted amongst children and adolescents up to 18 years of age who are not reported by the parents to the Agricultural Social Insurance Fund (KRUS). Thus the problem is marginalized, and it shall be an important part of education and awareness amongst the rural community, all the more so that half of the farms is run by people who have no agricultural education [7-9].

The analyzis of the structure of injuries on farms in the Kraśnik district confirms that most injuries occurred to the upper limb (42.16\%) and lower limb (27.45\%). It clearly correlates with the Agricultural Social Insurance Fund (KRUS) data where upper limb injuries took the first place with the result of $49.57 \%$ of injuries and the lower limb took the second place with the result of $37.69 \%$ of injuries. However, the least frequent were the serious injuries of the chest, spine, abdomen and pelvis, which ranked in the last position with the result of $11.76 \%$ in the district and $6.27 \%$ in the national Agricultural Social Insurance Fund (KRUS) data.

The analyzed medical records also showed a clear correlation of the occurrences of injuries depending on the season, notably in the Kraśnik district injuries most often took place in winter (33.3\%) and summer (30.4\%). In summer, the reason for this is most likely an increased amount of fieldwork, and the winter and spring, which is also confirmed by Jakubowski [10], they are related to the difficult weather and terrain conditions and may also be associated with the work associated with the preparation of firewood (e.g. cutting and chopping wood).

We observe a marked difference in the daily distribution of injuries where, as we could see in the details of patient admissions, usually the injuries occurred in the afternoon $(62.7 \%)$, which can be explained by increased fatigue, thereby increased lack of concentration of people working mostly from the early morning hours.

Comforting is the news that over the past twenty years the number of accidents recorded by the Agricultural Social Insurance Fund (KRUS) decreased from 65,936 to 25,772. Significant improvements of working conditions for farmers and their families that occurred in recent years are probably due to changes in the structure of agricultural farms and in the technology of production, as well as the acquisition of EU funds used for the purchase of modern machinery, equipment and production lines with a high standard of safety. As a result, large modern agricultural farms are created, managed by more skilled and educated young farmers, whereas small farms, where most accidents have been reported, are gradually excluded from the production.

\section{CONCLUSION}

1. The analysis of medical records implies that injuries in agriculture in the Kraśnik district usually occur amongst middle-aged men (40-49 years), which differs slightly from Agricultural Social Insurance Fund (KRUS) statistics for the population nationwide, but it also reveals a statistically significant $(9.8 \%)$ population of children and young people who are under 18 years of age and for that reason were not accounted for in the Agricultural Social Insurance Fund (KRUS) data.

2. Injuries that occur while working in agriculture are usually injuries of the upper and lower limbs, which fully coincides with the nationwide data.

3. Injuries in agriculture are characterized by seasonal occurrence and usually occur in the winter and the summer months.

4. The injuries in agriculture occur much more frequently in the afternoon.

\section{REFERENCES}

1. Gedliczka O, Brongel L, Biesiada Z, et al. Obrażenia ciała w badaniu prospektywnym: Cele i założenia pracy. Pol Surg Rev. 1993;65:451-60.

2. Szadkowska-Stańczyk I, Hanke W, Gdulewicz T. Analiza umieralności populacji w wieku produkcyjnym w Polsce. Med Pr. 1991;42:43-8.

3. Chowaniec C, Nowak A, Chowaniec M, Jabłoński C. Injuries of the vertebral column differentiating between natural illnesses manifested at work and illnesses caused by work accidents. Opinionating problems in cases associated with recognizing an event as a work accident in the analysis of materials of the Chair and Department of Forensic Medicine, Medical University of Silesia. Arch Med Sąd Kryminol. 2008;58(2-3):80-5.

4. Sokolov VA, Kartavenko VI, Garaev DA, Svirskaia LM. Syndrome of mutual aggravation of injuries in patients with a combined trauma. Vestn Khir Im I I Grek. 2006;165(6):25-9.

5. Kraśnik County Development Strategy for the period 2007-2015. Annex to resolution no. XII - 93/07 District Council in Kraśnik on 28 November 2007. [http://www.powiatkrasnik.bip.lublin.pl/upload/pliki/Strategia_Rozwoju_Powiatu_Krasnickiego.pdf.]

6. Wypadki przy pracy $\overline{\mathrm{i}}$ choroby zawodowe rolników oraz działania prewencyjne KRUS w 2011 roku. Warszawa: KRUS; 2011. [http:// www.krus.gov.pl/fileadmin/moje_dokumenty/dokumenty/prewencja/ raporty/wypadki_2011_web_zm.pdf]

7. Madras M, Kos M, Stefanek J. Przyczyny i rodzaje urazów narządu ruchu chorych hospitalizowanych w Oddziale Chirurgii Urazowej Szpitala Powiatowego w Kraśniku w czasie jednego roku. Acta Medica Premisliensia. 2002;23:46-51.

8. Brzeziński M, Zwinogrodzki J. Analiza statystyczna urazowości na podstawie materiału Kliniki Ortopedycznej AM w Warszawie. Chir Narz Ruchu Ortop Pol. 1963;28:407-13.

9. Szpinda J, Szymański B, Kos W. Wypadkowość związana z pracą w rolnictwie w materiale Oddziału Ortopedyczno-Urazowego Wojewódzkiego Szpitala Zespolonego w Zamościu. Chir Narz Ruchu Ortop Pol. 1996;61(Suppl. 2):453-5.

10. Jakubowski R. Dotychczasowe badania z zakresu medycyny pracy w rolnictwie i leśnictwie. Med Wiej. 1974;9:209-21.

\section{Informacje o Autorach}

Dr n. med. MAREK Kos - z-ca dyrektora ds. Medycznych SPZOZ w Kraśniku; lek. med. Henryk GomuŁa - starszy asystent, Oddział Chirurgii Ogólnej z pododdziałem Chirurgii Endoskopowej SPZOZ w Kraśniku; dr n. med. BArtŁomiej Drop - adiunkt, Katedra i Zakład Zdrowia Publicznego, II Wydział Lekarski z Oddziałem Anglojęzycznym, Uniwersytet Medyczny w Lublinie.

\section{Corresponding Author}

Dr n. med. Marek Kos

ul. Chopina 13, 23-200 Kraśnik

tel. 695-330-700

E-mail: marekkos@op.pl 